\title{
TORGING A SOCIALIST HOMELAND 1 FROM MULTIPLE WORLDS: NORTH 1 AMERICAN FINNS IN SOVIET KARELIA 1921-1938
}

\section{Kitty Lam}

Michigan State University, E-mail: lamkitt1@msu.edu

\begin{abstract}
:
In the early 1930s, the Soviet Union recruited an estimated 6,000 Finns from North America to augment the number of skilled workers in the recently established Karelian Autonomous Republic. Using migrants' letters and memoirs held at the Immigration History Research Center, this essay examines how these North American Finns adapted and responded to fluctuating policies in the Soviet Union that originally flaunted the foreign workers as leaders in the Soviet modernization drive and as the vanguard for exporting revolution, but eventually condemned them as an enemy nation to be expunged. It also analyzes the extent to which these immigrants internalized 'building socialism' as part of their encounter with Soviet Karelia. Such an exploration requires assessing how these settlers' ideological adaptation affected their experiences. This paper argues that by placing the North American Finns' experience in the wider context of Soviet state building policies, these migrants' identity formation involved participation in, avoidance of, and opposition to the terms of daily life that emerged within the purview of building socialism.
\end{abstract}

\section{Rezumat:}

La începutul anilor '30, Uniunea Sovietică a recrutat un număr estimat la 6.000 de finlandezi din America de Nord pentru a mări numărul de muncitori calificați din Republică Autonomă Kareliană recent constituită. Prin folosirea scrisorilor şi memoriilor imigranților păstrate la "Centrul pentru Cercetarea Istoriei Imigratiei" (Immigration History Research Center), acest articol examinează modalitatea în care aceşti finlandezi nord-amerciani s-au adaptat şi au răspuns politicilor fluctuante din Uniunea Sovietică care inițial i-au prezentat pe muncitorii străini drept lideri ai avântului sovietic de modernizare şi ca avangardă in vederea exportului de revolutie, iar apoi i-au condamnat ca pe o națiune inamică care trebuie eliminată. Articolul analizează, de asemenea, măsura în care aceşti imigranți au interiorizat "construcția socialismului" ca parte a întâlnirii lor 
cu Karelia Sovietică. O asemenea investigație necesită evaluarea modului în care adaptarea ideologică a acestor imigranți le-a afectat experiențele lor de viață. Acest material argumentează că prin plasarea experienței finlandezilor nord-americani in contextul mai larg al politicilor sovietice de constructie statală, formarea identității acestor imigranți a implicat concomitent participarea, evitarea şi opoziția față de situațiile vieții cotidiene născute in procesul de constructie a socialismului.

Keywords: Finns; migration; socialism; nationalities; Karelia; Soviet Union; Stalinism; Finnish-Americans

A massive figure stands in Petrozavodsk, the capital city of the Russian Republic of Karelia. Eleven meters tall and weighing 140 tons, this granite structure has dominated the city's core since it was constructed by Canadian and American Finns in 1933. During the Soviet era, residents regularly gathered here to commemorate Soviet holidays. Today, this memorial remains a testament to those migrants who sought to build their socialist paradise in the land of their ethnic kin.

This essay investigates how and why North American Finnish migrants to Soviet Karelia adapted and responded to the Soviet Union's constantly evolving policies. ${ }^{1}$ I argue that the North American Finns' ideological beliefs colored their comparison of hardship in their communities of origin and destination, which conditioned their adaptation in Soviet Karelia. How ever tragic these migrants' fate, many of these individuals genuinely believed that they could contribute to their new proletarian homeland by enduring austere circumstances. These migrants' decisions were neither random nor irrational. Men and women made calculated decisions on whether to migrate, who out of the family should move, and when to do so, based on their understanding of potential costs and benefits relocation would have on their families' lives. These decisions played into migrants' experiences in their destinations.

Using letters and memoirs written by migrants from different social contexts, this essay compiles a picture of the variegated ways migrants reconciled with their social and political circumstances. Lauri and Sylvia Hokkanen, who moved to Karelia from Michigan in 1934 and returned to the United States in March 1941, published their memoir in the 1980s.2

\footnotetext{
1 Although American Finns' testimonies form the primary source base for this essay, I refer to the migrants as North American Finns throughout to acknowledge similarities in social, cultural and economic circumstances between Canadian and American Finns.

2 Lawrence and Sylvia Hokkanen, Karelia: A Finnish-American Couple in Stalin's Russia, 19341941 (St. Cloud, MN: North Star Press, 1991).
} 
Other memoirs and correspondences are held at the University of Minnesota's Immigration History Research Center. Enoch Nelson, born in Northern California in 1897 to Finnish immigrants, was among the first North American Finns to seek his fortunes in Soviet Karelia in 1921. His trials and tribulations in Karelia are reflected in letters he wrote to his brother until 1933. Enoch was arrested and shot by the NKVD in $1938 .^{3}$ Kaarlo Tuomi's unpublished English-language memoir, To Hell, Allegiance: Psychology of a Double Agent tells of his experience as a teenager who moved to Karelia with his family in 1933. ${ }^{4}$ Having served for the Red Army, the GRU, and then the FBI, Kaarlo wrote a sensational story of his struggles with a divided sense of loyalty. Finally, Reino Mäkelä's letters to boyhood friends recount his teenage adventures in Karelia. He spent the rest of his life in the Soviet Union. These sources should not be read as an accurate description of daily life in Soviet Karelia. Rather, they represent perceptions these migrants wished to convey to their peers, and reveal the tensions between their aspirations and their actual situations.

This sketch of migrants' personal perspectives is inspired by other scholarly research on the political aspect of the Soviet Karelia exodus. Michael Gelb and Auvo Kostiainen both emphasize contradictory Soviet policies made the application of political terror against the Finns in Karelia remarkable. ${ }^{5}$ Irina Takala underscores the victimhood of people caught in the excesses of state-orchestrated violence. ${ }^{6}$ Reino Kero's comprehensive monograph, based on accounts of those who returned to North America,

\footnotetext{
3 Enoch Nelson's son Viktor and grandson Sergei learned in 1992 that Enoch had been shot on March 5, 1938. Through the efforts of Mayme Sevander, who conducted research in the early 1990s on the North American Finns in Soviet Karelia, Viktor, Sergei and Enoch's other Russian descendants connected with Allan Nelson, Enoch's American nephew (Arvid Nelson's son). See Allan Nelson, The Nelson Brothers: Finnish American Radicals from the Mendocino Coast, ed. Russell and Sylvia Bartley (Ukiah, CA: Mendocino County Historical Society and Mendocino County Museum, 2005), and Allan Nelson's long biographical essay, "Uncle Enoch," in the Arvid Nelson Papers, Finnish American Collection, Immigration History Research Center (hereafter IHRC), University of Minnesota, Box 11, Folder 9.

${ }^{4}$ Kaarlo Tuomi, with Dr. Daniel Wiener, To Hell, Allegiance: Psychology of a Double Agent, the Kaarlo Tuomi Papers, Finnish American Collection, IHRC, University of Minnesota. This manuscript was written and deposited at the IHRC in the 1970s.

5 Michael Gelb, "Finnish Immigrants during Stalin's Purges," Europe-Asia Studies, 45, no. 6 (1993): 1105, and Auvo Kostiainen, "Genocide in Soviet Karelia: Stalin's Terror and the Finns of Soviet Karelia," Scandinavian Journal of History 21, no. 4 (1996): 340.

${ }^{6}$ Irina Takala, "From the Frying Pan into the Fire: North American Finns in Soviet Karelia," in Karelian Exodus: Finnish Communities in North American and Soviet Karelia during the Depression Era, ed. Ronald Harpelle, Varpu Lindstrom and Alexis E. Pogorelskin (Beaverton, ON: Aspasia Books, 2004), 114-115.
} 
captures the deception and disappointment the returnees felt. ${ }^{7}$ This study departs from the above texts in that it combines the voices of those who returned from the Soviet Union and those who did not to assess how the political, social and personal dimensions of re-migration intertwined.

\section{Information Networks, Transnational Connections}

Enoch Nelson's decision to leave America reveals the significance of micro-level family dynamics as they interacted with meso-level regional economics and information networks. Enoch first learned of opportunities in Karelia through his older brother Arvid. As editor of the Finnishlanguage socialist newspaper Työmies in Superior, Wisconsin, Arvid was among the first to learn of Soviet government plans to build a workers' commune in Karelia. ${ }^{8}$ Arvid desired to accompany his Wisconsin acquaintances to Karelia, but due family responsibilities, declined to embark on this journey. Although socialism held bright promises for immigrant workers in North America, family economy and emotive bonds to the home factored significantly into migration decisions.

Arvid encouraged his younger brother to explore this opportunity, suggesting that Enoch could relay information about Karelia to his peers in America: "You could...go out there as experienced loggers, blacksmiths, timbermen, or the like, and if the conditions were alright, others could come later."9 This led Enoch to request further information on the organizations responsible for sending technical aid to Karelia. As early as 1921, ethnic Finnish communities in the Great Lakes basin and elsewhere in North America took seriously the notion of filling industrial labor needs in Karelia. Letters between Enoch and Arvid reveal young men's curiosity about the wider world, but they also suggest that these men were keen to explore opportunities that might benefit those in their social circles.

Although circumstances driving individuals to move to the Soviet communes in the 1920s differed from those that prompted the migrations in the 1930s, the earlier settlers provided important channels of information about an unfamiliar country. Migrants like Enoch Nelson enabled peers in America to learn more about conditions and opportunities in Karelia. Arvid published some of his brother's letters in Työmies. Through these

\footnotetext{
7 Reino Kero, Neuvosto-Karjalaa rakentamassa: Pohjois Americkan suomalaiset tekniikan tuojina 1930-luvun Neuvosto-Karjalassa (Helsinki: Suomen Historiallinen Seura, 1983), 202.

8 In addition to Soviet Karelia, there were other agricultural communes established in the Soviet Union in the 1920s. For example, a group of Americans founded the Seiatel commune in the North Caucasus region in 1922.

${ }^{9}$ Letter from Arvid to Enoch Nelson, January 22, 1921, in the Arvid Nelson Papers, Finnish American Collection, IHRC, University of Minnesota, Box 5, Folder 6.
} 
publications, co-ethnics caught glimpses of life in Karelia. The immigrant labor press also featured articles praising industrial and social developments in the Soviet Union, thus providing North Americans an optimistic view of life in the world's first socialist state. For example, Työmies congratulated the Soviet state for modernizing "the darkest corner of the (former) Tsarist state" by building a power station in Kondopoga, a noticeable step toward building socialism. ${ }^{10}$ Another editorial lauded the Soviet government for establishing industry, cultivating civilization, and creating schools and universities that provided opportunities for Finnish socialists in Karelia. ${ }^{11}$ By the time the Soviet government approved the recruitment of North American Finnish workers to Karelia in 1931, Finnish ethnic communities across the continent had already formed their own opinions. Propagandistic material in the immigrant labor press, along with messages successful sojourners sent home, inculcated a strong faith in socialism that would mediate migrants' experiences as they adapted to their new surroundings in Soviet Karelia.

In the early 1930s, the Soviet government promoted the immigration of North American Finns to bolster Karelia's Finnish-speaking population as part of what Terry Martin calls the affirmative action policy for dealing with the plurality of ethnic groups in the Soviet Union. ${ }^{12}$ In Karelia, Soviet authorities hoped that bolstering the Finnish-speaking population through the in-migration of socialist-oriented Finns from North America would contribute to the spread of Bolshevism to Finland and Scandinavia. This strategy was the so-called Piedmont Principle of the affirmative action policy, whereby Lenin and Stalin sought "to exploit cross-border ethnic ties to project political influence into neighboring states."13

The original impetus for this labor migration scheme, however, did not originate from party bosses in Moscow. This scheme came about through careful negotiation between party executives in Moscow and the leaders of the Soviet Karelian Autonomous Republic, Edvard Gylling and Kustaa Rovio, who originally envisioned this plan. Gylling saw Karelia as a stepping-stone toward nation-building for a "Greater Red Finland." $\mathrm{He}$ sought to transform Karelia into a modern socialist entity, which would inspire the Finnish population to bring about socialist revolution in their own country, and dissolve Finland's "unnatural" eastern border with

\footnotetext{
10 Työmies, February 19, 1929.

11 Työmies, August 7, 1929.

12 Terry Martin, The Affirmative Action Empire: Nations and Nationalism in the Soviet Union, 1923-1939 (Ithaca, NY: Cornell University Press, 2001), 9.

13 Martin.
} 
Soviet Karelia. ${ }^{14}$ The problem, however, was that the Karelian population in 1920 was approximately 210,000, of which only two per cent were industrial workers. The remainder consisted mostly of illiterate peasants and unskilled workers. Gylling therefore viewed the import of radically minded, Finnish-speaking workers as a crucial component for exporting revolution to Finland.

The Central Committee of the All-Russian Communist Party (TsK) initially concluded in 1922 that a mass influx of Finnish workers "could provoke nationalistic resentments among less skilled Russian workers displaced from their employment. Free immigration to the Soviet Union should be upheld as a principle of the workers' state...but not encouraged in practice." 15 Markku Kangaspuro notes that immigration had been a tense issue between regional leaders in Karelia and Communist Party central organs, which feared that settling foreigners in the border region would threaten national security. ${ }^{16}$ Although Moscow opposed immigration, Gylling nonetheless appealed to Finnish radicals in North America to provide funds for assisting Karelia's economic development through the Karelian Office of the Society for Technical Aid to Soviet Russia. ${ }^{17}$ These transatlantic financial contacts were crucial for setting up and administering the official foreign labor recruitment campaign when it began with full approval from Communist Party authorities. In 1931, the Soviet government finally approved plans to recruit North American Finnish workers to Karelia, since the time was ripe to take advantage of skilled North American Finnish workers disillusioned by the economic crisis in the capitalist world.

These factors, however, do not explain how individuals obtained specific information about their potential destinations, nor do they hint at how potential migrants interpreted such knowledge. Migrant networks formed an important part of this equation. Early pioneers, such as Enoch Nelson, provided the much-needed details that supplemented news in the immigrant labor press. Some migrants attempted to provide a more balanced view of life in Soviet Karelia for peers back home. One migrant using the pseudonym V. Suomela commented in a pamphlet that not all those who returned from Karelia provided the prospective migrant with an

\footnotetext{
14 Nick Baron, Soviet Karelia: Politics, Planning and Terror in Stalin's Russia, 1920-1939 (London: Routledge, 2007), 36.

15 Ibid., 74.

16 Markku Kangaspuro, "Nationalities Policy and Power in Soviet Karelia in the 1920s and 1930s," in Communism: National and International, ed. Kimmo Rentola and Tauno Saarela (Helsinki: Finnish Historical Society, 1998), 126.

17 Baron, 64.
} 
accurate picture of Karelia. Some only exalted the Soviet system, while others expressed only bitterness for their hardships. Suomela argued that realities in Karelia lay in between these extremes. He agreed that socialism would one day be the salvation of all workers, but in the meantime, Soviet society was not perfect, and its improvement would have to rely on workers' sacrifice. ${ }^{18}$ Migrants often make adjustments to mental perceptions of their reality; these amendments filtered back as information in letters to friends and kin in the migrant's place of origin. But while these letters provide differentiated views of the migrant's conditions, the gap between limitless hope and unlimited opportunity is never resolved. ${ }^{19}$

Enoch Nelson's letters hint at such internal tensions. Writing to his brother from Petrozavodsk in December 1930, he observed, "The people coming over here now have it much easier than what it was when I came over but even then it takes them a few days to get used to things...Our fight for socialism has brought forward many new steps in the manner of living to which the newcomers have to be accustomed to before they feel at home." 20 Such testimonies provided a detailed picture of life in Karelia, but it is also possible that letter writers crafted their messages with the censors in mind. Likewise, those receiving such messages had few tools for assessing the writers' earnestness, and could not know for certain whether the sender's expressions were self-censored. Although the potential migrants may have learned to expect harsh and unpredictable conditions in the initial phases of the move, the realities of their point of arrival appeared to be something for which they were utterly unprepared.

The gendered nature of the labor recruitment campaign influenced family decisions. The bulk of ads in the socialist Finnish immigrant press in Canada and the United States advertised jobs dominated by men. For example, the Soviet Karelian Technical Aid Society's ad called for 250 fishers to apply for work in Soviet Karelia. ${ }^{21}$ Given this preference in advertising, the majority who applied to go to Karelia were single adult men. Some adult women did venture to Karelia on their own, and some adult men brought their wives and children along.

\footnotetext{
18 See V. Suomela's pamphlet, Kuusi kuukautta Karjalassa: mitä siirtolainen näki ja koki Neuvosto-Karjalassa, published by the newspaper Vapaa Sanaa in Sudbury, ON, date unknown, in the Arvid Nelson Papers, Box 9, Folder 9. According to the IHRC's records, this pamphlet was likely published in 1933-34.

${ }_{19}$ Dirk Hoerder, "From Dreams to Possibilities: The Secularization of Hope and the Quest for Independence," in Distant Magnets: Expectations and Realities in the Immigrant Experience, 1840-1930, ed. Hoerder and Horst Rössler (New York: Holmes and Meier, 1993), 3.

20 Letter from Enoch to Arvid Nelson, December 28, 1930, in the Arvid Nelson Papers, Box 5, Folder 12.

21 Työmies, July 28, 1932.
} 
These gendered dynamics sometimes led to tensions within families. Kaarlo Tuomi recalls that in Michigan, the Great Depression displaced his stepfather from his work at lumber camps. Kaarlo's mother thus became the family's sole breadwinner, while his stepfather did the household chores, which he perceived as emasculating. The prospect of labor migration to the Soviet Union changed this situation, as Kaarlo's stepfather saw in it his "best chance for vital labor freed from housework he felt demeaning." Kaarlo's mother, on the other hand, did not want to move, but in the end acquiesced to her husband's insistence. ${ }^{22}$

Rumors about benefits the Soviet Union accorded to workers likely gave prospective migrant laborers a positive view of life in Karelia. One report claimed, "The majority of workers in the Soviet Union now do work for seven hours a day. The shortening of the work day accompanies raises in wages, new housing, and improved relations with other workers." 23 Workers who had been accustomed to long hours, low wages, and lack of protection from employers' abuse likely found such reports attractive.

The majority of those who departed were not necessarily the most destitute of oppressed workers in the Great Lakes basin mining and logging camps. Lauri and Sylvia Hokkanen were among young, childless couples who were more prosperous than some of their neighbors in northern Michigan. The Hokkanens nonetheless worried about their future during an economic crisis, and saw Karelia as a viable option for sustaining their livelihoods. ${ }^{24}$ Most migrants were aware that living conditions could be tougher in Karelia than in Depression-ridden United States. One recruiting agent, Comrade Kuismanen, informed prospective migrants that shortages of material goods still persisted in Karelia. At the same time, he also anticipated that these difficulties would be overcome in due time. Kuimanen alluded that hardship in the Soviet Union was tolerable because there it at least offered a glimmer of hope for improvement..25

Some of the more affluent North American Finns moved their entire families to Karelia. They were driven more by idealistic visions of socialism than abject poverty. Some believed in socialism so fervently that they even paid for the passage of destitute workers who could not otherwise have assumed relocation costs. Oscar Corgan, a chairmen of the Karelian

\footnotetext{
22 See Kaarlo Tuomi memoir manuscript, To Hell, Allegiance: Psychology of a Double Agent, in the Kaarlo Tuomi Papers, Finnish American Collection, IHRC, University of Minnesota. This manuscript was written and deposited at the IHRC in the 1970s.

23 Työmies, October 30, 1932.

24 Hokkanen and Hokkanen, 9.

25 Työmies, November 26, 1931.
} 
Technical Aid Society, was one such migrant. His idealism prompted him to move his wife and children to Karelia in 1934.26

In the first years of the labor recruitment campaign, migrants voyaged in groups. Reino Mäkelä recalled that he traveled with two other families from his hometown of Waukegan, Illinois. Upon arrival in Petrozavodsk, authorities even assigned these famillies to the same living quarters. ${ }^{27}$ Manifests of the major shipping lines carrying migrants from ports in the eastern United States to Karelia via London or Stockholm confirm that from 1931 to 1934, Finnish migrants to Karelia travelled in groups of varying sizes. ${ }^{28}$ On each of these voyages, much pomp, circumstance, and official propaganda greeted the eager migrants. One sojourner recalls that on the ship from London to Leningrad, a Soviet representative welcomed the Karelia-bound passengers with a rousing speech about fulfilling the Five Year Plan in four years. ${ }^{29}$

\section{Local Interactions and Tensions}

For migrants like Reino and his family the journey itself, which lasted several weeks, and their relocation with peers in the same neighborhood represented a bonding experience. These community ties helped migrants mitigate the initial isolation of their new surroundings and the material shortages they faced. The clustering of migrants in the same locations is not an unusual phenomenon. As Dirk Hoerder notes, such clustering of people from similar backgrounds occurred everywhere: newcomers from rural French provinces lived in the same Parisian neighborhoods, and Italian migrants from a particular region settled near

\footnotetext{
26 Oscar Corgan's daughter, Mayme Sevander, later wrote her own personalized account of the "Red Exodus" of North American Finns to Karelia. See Mayme Sevander, Red Exodus: Finnish-American Emigration to Russia (Duluth, MN: OSCAT, 1993).

${ }^{27}$ Letter from Reino Mäkelä to Benny Mäki, no date, in the Reino Makelä Papers 1915-1977, Finnish American Collection, IHRC, University of Minnesota, Folder 3, 1931-32.

28 Rudolph Pinola, "Finnish American Emigration to Soviet Karelia in the Early 1930s," in the Rudolph Pinola Papers, Finnish American Collection, IHRC, University of Minnesota, Folder 1. Pinola's list of 1300 passengers (revised in 1995) who traveled to Soviet Karelia in the early 1930s was based on passenger lists of North American Finns destined for the Soviet Union, supplied by major shipping lines from American to European ports. This list, however, is not exhaustive, as the shipping lines at times supplied only the names of the individual who paid for the passage, and did not include names of individuals accompanying the paying traveler. It is also impossible to determine from these ship manifests which of the migrants stayed in Karelia temporarily, and which ones stayed permanently. Such information may be available from the documents at the Republic of Karelia State Archive of Modern Political History (KGANI).

29 Työmies, August 6, 1931.
} 
each other in the United States, France, and Germany. ${ }^{30}$ What makes the Finnish case in Karelia striking is that Soviet state policy deliberately encouraged such clustering to promote ethnic institutions in the Soviet border regions. ${ }^{31}$ Throughout the late 1920s and early 1930s in Karelia, Finns filled management positions in factories, were educated in Finnishlanguage schools, and formed vibrant ethnic communities. The FinnishAmerican newspapers reported plans to establish a new, national university in Karelia to train Finnish speaking youth in various fields. ${ }^{32}$ Sylvia Hokkanen enrolled in the Pedagogical Institute in Petrozavodsk soon after her arrival. She recalls that students, who were Finns from North America and Finland, got along amicably. ${ }^{33}$

The Soviet leadership lumped the North American Finns with migrants from Finland, and at times treated Finns as an undifferentiated ethnic category. The estimated 6,000 North American Finns in Karelia should be distinguished form the 12,000 to 15,000 Finns who illegally crossed the Finnish-Soviet border. ${ }^{34}$ The North Americans, though not a monolith, were more radically minded, and their decision to migrate stemmed from ideological almost as much as economic motives. The illegal border hoppers from Finland, on the other hand, were mostly economic refugees escaping poverty and famine in Finland. These two groups should be further distinguished from those among the 18,000 ethnic Finns, mostly peasant farmers, from the Leningrad region who were deported to Karelia. ${ }^{35}$ When the collectivization drive began in 1928 approximately 4,000 families who had allegedly opposed collectivization were dispersed to forestry work in Karelia and the apatite mines of the Kola peninsula, as well as to Central Asia. ${ }^{36}$ Auvo Kostiainen's study of illegal Finnish

\footnotetext{
30 Dirk Hoerder, "From Migrants to Ethnics: Acculturation in a Societal Framework," in European Migrants : Global and Local Perspectives, ed. Dirk Hoerder and Leslie Moch (Boston: Northeastern University Press, 1996), 245.

31 Martin, 315.

32 Työmies, April 2, 1931.

33 Hokkanen and Hokkanen, 29-30.

34 The 6,000 North American Finns in Karelia include only those who traveled between 1931 and 1934, the years of the Soviet Karelian Technical Aid Society's official labor migration campaign. This figure does not include the several hundred who left for Karelia in the 1920s. 35 See Timo Vihavainen, "Framing the Finnish Experience," in Karelian Exodus: Finnish Communities in North American and Soviet Karelia during the Depression Era, eds. Ronald Harpelle, Varpu Lindstrom and Alexis E. Pogorelskin (Beaverton, ON: Aspasia Books, 2004), and Irina Takala, Finny $v$ Kareliia $i v$ Rossii (St. Petersburg, Russia: Neva, 2002) for data on Finnish migrants from North America and from Finland. See also Ian Matley, "The Dispersal of the Ingrian Finns," Slavic Review 38, no. 1 (1979).

36 Matley, 9.
} 
migrants in Soviet Karelia suggests that the three very different groups of Finns rarely interacted with each other. ${ }^{37}$

This ethnic makeup in Karelia underscores a particularly perplexing situation in the Soviet Union: at the same time as Soviet state authorities recruited ethnic Finns from North America to fulfill leadership roles in Karelia's industries, the Soviet government also coerced ethnic Finns from Russian territories to fill arduous tasks in the region. The Soviet industrialization drive prioritized skilled laborers and technical expertise. Soviet government leaders were aware of Finns' sense of dissatisfaction in North America and their desire to search for a better future in a different location. At the same time, the government viewed Ingrian Finns as saboteurs who resisted state policies. This phenomenon demonstrates that coerced and free migration regimes interacted with each other, as with the value systems that enabled these streams. ${ }^{38}$

The North American Finns also stood out because a number of them brought material goods that were rare in the Soviet Union. Sylvia Hokkanen notes that most immigrants either took all they could afford to take in clothing, food and tools, or used their savings to buy whatever cars, trucks or farm equipment that could be shipped for use in Karelia. ${ }^{39}$ Finnish cooperative stores also encouraged travelers to purchase all sorts of material goods to take with them to Karelia. One such enterprise placed an ad in Työmies enticing travelers to purchase typewriters, fountain pens and other writing materials, phonographs and records, and clocks. ${ }^{40}$

The ability of North American Finns to transfer materials and equipment to the Soviet Union was already common for the initial group of migrants who set up Soviet communes in the 1920s, albeit in a differnt context. Enoch Nelson dealt with the shortage of material goods in Karelia when he arrived in the early 1920s by asking his brother in Wisconsin to send him whatever could be sent. ${ }^{41}$ Enoch Nelson's awareness that the foreign worker's standard of living was above the average standard of the

\footnotetext{
37 See Auvo Kostiainen, Loikkarit: Suuren lamakauden laiton siirtolaisuus Neuvostoliittoon (Helsinki: Otava, 1987).

38 David Eltis, "Free and Coerced Migrations from the Old World to the New," in Coerced and Free Migration: Global Perspectives, ed. David Eltis (Stanford, CA: Stanford University Press, 2002), 36.

39 Hokkanen and Hokkanen, 10.

40 Työmies, September 8, 1932.

${ }^{41}$ Letter from George Halonen of the Soviet Karelia Relief Committee to Arvid Nelson, June 19, 1922, in the Arvid Nelson Papers, Box 5, Folder 7. Halonen informed Arvid that it cost $\$ 145.81$ to send to Enoch in Karelia the list of requested items sent to the Soviet Karelia Relief Committee on May 29, 1922. Halonen also noted that some of the tools Enoch requested would be sent with subsequent groups of travelers to Karelia.
} 
Russian worker suggests he also possessed a missionary sense of superiority. His writings imply that he and other foreigners were helping to bring the "backward" Russian and Karelian workers up to a higher standard of living:

These people have never had anything except the black bread and some hot water....Now they are getting as much bread as they can eat...Then they are also learning to read and write and understand the things of the world so that some day they will be intelligent enough to ask for something for themselves. ${ }^{42}$

The North American Finns' distinctiveness raises another important issue. The Soviet government recognized that catching up to and overtaking Western capitalist societies required the expertise of foreign industrial workers accustomed to different lifestyles. To attract North American Finns to the Karelian hinterland, the Soviet government initially provided these migrants attractive benefits: better food, more spacious living quarters, and access to Insnab stores closed to ordinary Soviet citizens. Did these North American Finns, many of whom were selfproclaimed radicals who swore by ideals of equality, consciously accept this Faustian bargain upon their arrival in Karelia? Did their revolutionary zeal plague their conscience for accepting these enticements? Young Kaarlo Tuomi was sent away from his family to work at a labor camp. It was only when he visited his family after a three year absence and found that their conditions had worsened considerably that it dawned on him his family had been receiving favorable treatment as new immigrants. They had enjoyed privileges such as larger food rations and better housing, "which made the older residents bitterly jealous." 43

More importantly, one should also meditate on how this Faustian bargain contributed to the Terror's intensity against the North American Finns. This requires taking the larger framework of Soviet state building into account. State orchestrated violence in the name of the socialist offensive affected the North American Finnish migrants to Karelia immensely. These individuals arrived in the Soviet Union as active participants in the Soviet industrializing mission, and came into direct confrontation with the state as this undertaking unfolded with increasing contradictions and unintended consequences.

When the Soviet state retreated from the "indigenization" campaign, which had promoted the Finnish language and nationality in the

\footnotetext{
42 Letter from Enoch to Arvid Nelson, in the Arvid Nelson Papers, Box 5, Folder 7.

43 The Kaarlo Tuomi Papers.
} 
1920s and early 1930s, North American Finns who had taken Soviet citizenship became the diaspora of a neighboring bourgeois state, and were treated as a dangerous foreign capitalist element, even though many still affirmed their missionary role as the vanguard of Soviet modernization. Any acts, how ever remote from the present, which had previously aroused the tiniest hint of resentment in the native population, were used as proof of the foreigner's "nationalist" chauvinism. The higher salaries the North American Finns earned and the privileges the Soviet state had originally granted them were further proof of guilt. ${ }^{44}$ The Soviet leadership's initial preference for these migrants inadvertently made them susceptible to subsequent labeling as bourgeois, enemy nationalist spies bent on sabotaging Communism. These changes in perceptions of "foreignness" and "enemy elements" demonstrate the baffling contradictions embedded in Soviet state policy.

Migrants enrich receiving societies by changing their cultural landscape. As part of the acculturation process, migrants often re-created their cultural traditions, fusing them with local ones in their new surroundings. For the North American Finns, replicating their social and cultural institutions in the Soviet Union enabled them to plant roots in their new Soviet homeland on their own terms. They formed baseball and other sports teams. The migrants constructed cultural halls for their recreational programs. These halls also served as meeting places for the Komsomol and Pioneers. ${ }^{45}$ For young migrants like Reino Mäkelä and his friends, the rich migrant cultural life in a new setting gave them a sense of adventure. Reino and his friends went to dances with local Russian girls. They frequented parks and attended band performances. ${ }^{46}$ These cultural connections to their places of birth gave these migrants a sense of agency in their future, even as tragedy befell them.

\section{The Subjective Socialist}

Soviet leaders' plans for building socialism employed multiple methods, touching upon myriad aspects of life for those witnessing this grandiose scheme. Turning workers into willing participants of the socialist project was a particularly significant process for foreign migrant workers in the Soviet Union. But what did building socialism mean for the actors involved? How did these North American Finns conceive of their own role

\footnotetext{
44 Vihavainen, 146-147,

45 Letter from Reino Makelä to Benny Mäki, March 5, 1932, in the Reino Makelä Papers, Folder 3.

${ }^{46}$ Letter from Reino Hämälainen to Benny Mäki, April 5, 1932, in the Reino Makelä Papers, Folder 3.
} 
in the socialist project? Literature on subjective interpretations of the socialist self is revealing for examining the lives of the men, women, and children who left their birthplaces and traded their homes in America for the Soviet dream. For a vast number of North American Finns, the majority of whom originated from a radicalized background, ideology was a significant motivating factor for moving to Soviet Karelia, though their idealism did not necessarily follow a teleological path toward socialist utopia. Their ideological motivation in building socialism was, of course, severely tested during the apex of Stalin's Terror. These migrants' experiences therefore evoke some unanswered questions about the role of ideology in an individual's identification with the state.

Subjective interpretations of building socialism must be filtered through a gendered lens, for these migrant men, women, and children experienced socialism differently. For Enoch Nelson and other men who migrated alone to Karelia under similar circumstances, their role as the pioneers of socialism in Karelia gave them a sense of pride. But for women who followed their husbands to an isolated destination, building socialism did not provide any sense of comfort. For Sylvia Hokkanen, the switch from being a school teacher to being someone who did odd jobs such as gathering moss and driving horses was a rather dramatic change. She recalls that none of these jobs made her feel very important, though she felt she was at least "doing something." 47

For Enoch Nelson, the road to being a socialist man was not always a straightforward one. Though his idealism prompted him to try his luck in the Soviet Union, his optimism waxed and waned along with changing circumstances. At times, his letters reveal skepticism and even downright frustration at what must have seemed nonsensical ways of running society. The NEP era wage scheme at the Onega blacksmith shop where he was employed particularly baffled him: "The wages...are so small that it is almost impossible to manage to make a decent living. I do not see how it is that they could not pay a person for all the work that he does even if he earned a whole week's wages in one day. Even then I would not be above the American standard and I know that my work was profitable for the American capitalists and I did not do a bit more than what I am doing here." 48 Within a year of arrival, Enoch contemplated returning to America, but he soon developed a sense of mission in building socialism that rooted him to the Soviet Union. He told his brother, "When I first came here the morale was very low and it seemed as if everything was going to the dogs.

\footnotetext{
47 Hokkanen and Hokkanen, 27.

48 Letter from Enoch to Arvid Nelson, December 24, 1922, in the Arvid Nelson Papers, Box 5, Folder 7.
} 
Now things have taken a little change and the weaker ones are weeding out and we will soon have left only those who intend to stay, and then there is some change to make a success of this affair." 49

One aspect of migrants' lives that helped them identify with the socialist experiment was that they were, at least initially, welcomed as "technical experts." This gave the migrants a sense that they were involved in something more important and larger than themselves. Jochen Hellbeck's work on Stalinist era diarists offers insightful perspectives on the heroic aspects of socialist subjectivity. Heroism, and a sense that one was contributing to something truly unique and thus forging history, had powerful appeal. "In calling on Soviet citizens to involve themselves in the collective building of the new world, the leadership appealed to their heroic disposition. That disposition fueled their rationalist zeal, optimistic self-confidence, and creative energy." 50 To be true participants in this project involved tremendous self-transformation projects on the part of Communist activists. ${ }^{51}$ Hellbeck's work is therefore insightful for examining the extent to which migrants like Enoch Nelson were motivated by such beliefs.

Enoch Nelson relocated to Soviet Karelia during the beginning of the NEP years, when the Soviet authorities were willing to give more leeway to "bourgeois specialists." In the 1920s, Enoch's sense of importance came from having access to the latest information about new farm technology that very few in Russia could access. In 1924, Enoch moved to the American commune, Seiatel, in the Donbas region. During his years in Seiatel, he sought from his brother information on American farm equipment. In one letter, Enoch requested drawings and specifications for haymaking machines in use on American farms, with hopes he and his peers on the Seyatel commune might be able to replicate these machines. ${ }^{52}$ This was an important confidence boost for Enoch, who spent years making railway ties at a construction camp in California before moving on to more important posts in Soviet industry. For migrants who arrived later in Karelia during the official labor recruitment campaign in the early 1930s, their manpower was sorely needed in a land that still lacked an educated, technically savvy population to fill leadership roles in industry. Lauri

\footnotetext{
${ }^{49}$ Letter from Enoch to Arvid Nelson, April 14, 1923, in the Arvid Nelson Papers, Box 5, Folder 8.

50 Jochen Hellbeck, Revolution on My Mind: Writing a Diary under Stalin (Cambridge, MA: Harvard University Press 2006), 29.

51 Ibid., 19.

52 Letter from Enoch to Arvid Nelson, May 11, 1925, in the Arvid Nelson Papers, Box 5, Folder 10.
} 
Hokkanen, who worked at a sawmill in Michigan, was promoted to foreman of machine repair at the Gylling Ski Factory in Petrozavodsk. Soon after his promotion, he was sent with a team of engineers and foremen to inspect a ski factory in Moscow. ${ }^{53}$

The tragedy for Enoch was that just as he seemed to have overcome ethnically based attachments to society, which had become anathema to the new Soviet socialist rhetoric of the late 1930s, the Soviet state arrested him for being a bourgeois nationalist. His correspondence with Arvid does not indicate that he identified strongly either as an American or as a Finn; rather, his writings reveal a self-styled Soviet man who was immensely proud of his new citizenship. For the shapers of the socialist garden state however, Enoch's self-identification as a Soviet man did not matter so much because they saw him only as an ethnic Finn with bourgeois ties to fascists in neighboring Finland. By wartime, from the government's point of view, nationality presented the clearest and most present danger to the moral and political unity of the Soviet people. The fight against the recurrences of nationalist views became the most critical task in the socialist struggle against capitalism. ${ }^{54}$

The Soviet nationalities policy came with unintended consequences. Differentiating individuals by national identity essentialized ethnicity, and helped reify the "national enemy" as an ascribed social category. ${ }^{55}$ By 1938, the Soviet state had legally fixed ethnic categories, such that people could no longer determine their own nationality, as bourgeois nationalist became an abstract identity fixed to individuals. Thus, "the Great Purges illustrate how to name is to possess, sometimes with fatal consequences."56 The documents of the State Archive of the Social Political Movements and Formation of Karelia (GAOPDFK) record a number of cases where ethnic Finns, regardless of their country of birth, were arrested and accused of counterrevolutionary activity. One document implicates five workers from the International Tractor Factory for their counterrevolutionary crimes. These crimes included discrediting the policies of the Soviet and Karelian governments, challenging the factory leadership, and criticizing Stalin's constitution. In addition, these men were also accused of supporting

\footnotetext{
53 Hokkanen and Hokkanen, 41-42.

54 Amir Weiner, Making Sense of War: The Second World War and the Fate of the Bolshevik Revolution (Princeton, NJ: Princeton University Press, 2001), 37-38.

55 Terry Martin, "Modernization or Neo-Traditionalism? Ascribed Nationality and Soviet Primordialism," in Stalinism: New Directions, ed. Sheila Fitzpatrick (London: Routledge, 2000), 357.

56 Kate Brown, A Biography of No Place: From Ethnic Borderland to Soviet Heartland, (Cambridge, MA: Harvard University Press, 2003), 162.
} 
fascists in Finland and in Canada, proliferating fascist ideas, and spreading rumors about the death of Soviet leaders. ${ }^{57}$ Such was the indictment against thousands of those who believed fervently in advancing socialism.

Kaarlo Tuomi's socialist self developed along a path quite different from the one Enoch Nelson took, partly because of his age when he first relocated, and partly because he had not been in the Soviet Union for a long time before Soviet policies turned against the migrants. In his unpublished memoir, he reminisces about changes in his social environment that accompanied his family's move to Karelia. As a young adult in Soviet Russia, Kaarlo did what was expected of him. He worked industriously, coping with unfortunate circumstances to the best of his ability. Although he earned the Soviet worker's top honor as a Stakhanovite, he did not exhibit unquestioned faith in socialism. When his stepfather was arrested in 1937, leaving him with his mother and sister in dire circumstances, he adapted to his ascribed status as the relative of an "enemy of the people" by working even harder to ensure his family's survival.

His transformation into a loyal Soviet citizen did not come about until the German invasion of the Soviet Union in June 1941. According to his memoir, with this invasion, "his long probation in the U.S.S.R. thus suddenly ended...It was his fatherland that had been invaded, and alongside all his comrades, he would fight to the death for it. At last he was one with this land." 58 Amir Weiner argues that the Great Patriotic War provided a cataclysmic watershed where social and political harmony became the motto in Stalinist self-representations.59 The myth of war opened up room for re-defining criteria for legitimate membership in and exclusion from the Soviet family based on wartime conduct. 60 Perhaps the war gave Kaarlo the opportunity to demonstrate to the state that although he was the stepson of an "enemy of the people," he could redeem himself through heroic war efforts. He enlisted with the Red Army in the Continuation War against Finland, and was even assigned to an espionage mission in Finland, which was canceled because of the armistice between Finland and the Soviet Union. Fighting in the war provided for him a universalizing experience with fellow soldiers, and gave him a sense of purpose in the Soviet future. At the Red Army's service, Soviet leadership "seemed close and empathetic. Memories of the purges faded, as well as

\footnotetext{
57 Neizvestnaia Kareliia: dokumenty spetsorganov o zhisni Respubliki (Petrozavodsk, Russia: Karel'skii nauchnyi tsentr RAN, 1997), 267.

58 The Kaarlo Tuomi Papers.

59 Weiner, 23.

60 Ibid., 8.
} 
the obsessive indoctrination, cruelty and deprivations." 61 Tuomi's case supports Weiner's argument that the Second World War was an identity crucible for thousands of Soviet men and women.

Having gone through this transformation into identification with the state, Kaarlo's post-war experiences put his newfound faith in the Soviet system through severe tests. Like thousands of other Soviet citizens, he was blackmailed by the KGB into becoming an informant. When state security agents realized that Kaarlo spoke English with a perfect Midwest accent, they recruited him to be a spy, and sent him to America to serve his new fatherland. He felt that he was returning to "improve the land of his birth, to help rebuild it, someday, in the communist image."62 He was subsequently detained by the FBI and then blackmailed into betraying secrets of the Soviet espionage operations in the United States. Kaarlo Tuomi's memoir, although should not be taken at face value as the actuality of his experiences, nonetheless alludes to how psychological aspects of migration and acculturation had affected his interpretation of his encounter with Soviet state violence. His words suggest he thought of himself as a man trapped between competing ideologies. Having experienced the impossibility of discerning between right or wrong, he relied on his own agency to mitigate the effects of two superpower state agencies treating him as a pawn.

Reino Mäkelä's letters to his childhood friends and relatives provide yet another picture of how North American Finnish migrants might have developed their socialist consciousness. Like Kaarlo Tuomi, he had not been the kind of early pioneer in building socialism that Enoch Nelson had been. Reino's letters from 1931 to 1932 to his friend in Illinois, Benny Mäki, reveal a boy who viewed his move to the Soviet Union as a grand adventure. Although he did not make the decision to migrate on his own, since his parents were responsible for such decisions, sixteen-year-old Reino did not express any grievances against this move. His early years in Karelia were filled with freedom and pleasure: dances with local Russian girls, skiing, and visits to orchestral performances. He was even eager to work at the local ski factory, though he alleged that the ski factory did not hire him because as an underaged worker the factory could not employ him for more than six hours a day. ${ }^{63}$ Unfortunately, beyond 1932 we have little idea of Reino's coming-of-age experience in Soviet Karelia, as the

\footnotetext{
61 The Kaarlo Tuomi Papers.

62 Ibid.

63 Letter from Reino Mäkelä to Benny Mäki, March 5, 1932, in the Reino Makelä Papers,

Folder 3.
} 
Immigration History Research Center has no record of his letters to America between 1932 and 1958.

Reino's post-1958 letters to his cousin in the United States, Eva Helen Erickson, are revealing because of the silences about his experiences with the Terror and the Second World War. When he resumes writing letters to America, he tells his cousin "I'm still alive and well...Now starts this history of mine. It isn't long, nor so bad or sad. It's very good up to this time." In this letter, he reveals that he has married a Finnish woman and has two children. ${ }^{64}$ His parents and his brother Rudy are still living at the time of writing, and they spent part of the war years in the Crimea. Aside from basic facts about his family, he mentions nothing about his experiences during the purges or the war, or how he and his family managed to survive when so many of their friends had disappeared. He writes about everyday things - his health, the weather, and he sends requests for coffee and English-language books. His letters describe the life of a relatively well-adjusted Soviet citizen.

It was only in 1978 that he finally writes to Eva about the fate of his younger brother Kalervo and reveals some emotion about his family's ordeals:

He was young when he was arrested. We had a bad time in 1938 when a lot of Finns were arrested for nothing. Kalervo was in prison for 8 years and died in prison in 1946. When he died we got papers that he was innocent like a lot of people arrested at that time were and came home again. It was the enemies of this country that got into our higher organization. They were all arrested in 1939. Anniki's father was arrested too and he died in prison too. Innocent. Got the papers after they died. 65

These comments reveal several aspects of Reino's life: he likely knew that his relatives and friends were arrested for absurd crimes they did not commit; yet, he carried on with his own life. He might have been embittered by the purge experience, but could not or would not express anger in his correspondence. Perhaps that in spite of his friends' and family

\footnotetext{
64 Letter from Reino Mäkelä to Eva Helen Erickson, August 23, 1958, in the Reino Makelä Papers, Folder 1, 1958-1971. It is possible that more of Reino's letters in from the mid to late 1930s made it to his friends and relatives in America, and were simply not deposited with his collection at the Immigration History Research Center. However, in his 1958 letter, he also tells Eva that he has not written in English in over twenty years. Since all of his 19311932 correspondence were written in English, it is fairly reasonable to assume that he stopped writing letters to America completely in 1938.

65 Letter from Reino Mäkelä to Eva Helen Erickson, August 16, 1978, in the Reino Makelä Papers, Folder 2, 1972-1981. Anniki was Reino's wife.
} 
members' arrests, he still aspired to be a good Soviet citizen. On the one hand, pointing to foreign saboteurs in government as the reason for his brother's and his father-in-law's persecution could have been his way of writing about his family without appearing to be disloyal. On the other hand, he might also have been attempting to assert his trust in the Soviet system. These migrants' experiences allude to the complexities in subjective evaluations of the Great Terror.

\section{Conclusion}

This paper has drawn from disparate literatures - on migrant networks; Soviet nationalities policies; social and labor history; and on socialist subjectivity - to demonstrate that migrants' ideological convictions shaped their interpretation of their ordeals in Soviet Karelia. Although these individuals' encountered incongruence between expectation and reality, they were not merely helpless victims of Soviet repression. Migrant letters and memoirs illustrate that for some, their passion as active participants in building socialism punctuated their sense of victimhood. Their experience in Soviet Karelia reveals how ideals, combined with subjective interpretations of various social contexts, molded the migrants' encounter with socialism.

\section{References:}

\section{A. Archives:}

Immigration History Research Center (IHRC), University of Minnesota:

- Reino Makelä Papers 1915-1977: Folder 1, 1958-1971; Folder 2, 1972-1981;

Folder 3, 1931-32;

- $\quad$ Arvid Nelson Papers, Box 5, Folder 6; Box 5, Folder 7; Box 5, Folder 8; Box

5, Folder 10; Box 5, Folder 12; Box 9, Folder 9;

- Rudolph Pinola Papers;

- Kaarlo Tuomi Papers, Box 11, Folder 9; Manuscript To Hell, Allegiance: Psychology of a Double Agent.

\section{B. Published documents:}

Neizvestnaia Kareliia: dokumenty spetsorganov o zhisni Respubliki

(Petrozavodsk, Russia: Karel'skii nauchnyi tsentr RAN, 1997.

\section{Newspapers:}

Työmies, August 7, 1929; April 2, 1931; August 6, 1931; November 26, 1931; October 30, 1932; July 28, 1932; September 8, 1932

\section{Books and articles:}


Baron, Nick. Soviet Karelia: Politics, Planning and Terror in Stalin's Russia, 1920-1939. London: Routledge, 2007.

Brown, Kate. A Biography of No Place: From Ethnic Borderland to Soviet Heartland. Cambridge, MA: Harvard University Press, 2003.

Eltis, David. "Free and Coerced Migrations from the Old World to the New." In Coerced and Free Migration: Global Perspectives. Ed. David Eltis. Stanford, CA:

Stanford University Press, 2002

Gelb, Michael. "Finnish Immigrants during Stalin's Purges." Europe-Asia Studies 45, no. 6 (1993).

Hellbeck, Jochen. Revolution on My Mind: Writing a Diary under Stalin. Cambridge, MA: Harvard University Press 2006.

Hoerder, Dirk. "From Dreams to Possibilities: The Secularization of Hope and the Quest for Independence." In Distant Magnets: Expectations and Realities in the Immigrant Experience, 1840-1930. Ed. Hoerder and Horst Rössler. New York: Holmes and Meier, 1993.

Hoerder, Dirk. "From Migrants to Ethnics: Acculturation in a Societal Framework." In European Migrants : Global and Local Perspectives. Ed. Dirk Hoerder and Leslie Moch. Boston: Northeastern University Press, 1996.

Hokkanen, Lawrence and Sylvia. Karelia: A Finnish-American Couple in Stalin's Russia, 1934-1941. St. Cloud, MN: North Star Press, 1991.

Kangaspuro, Markku. "Nationalities Policy and Power in Soviet Karelia in the 1920s and 1930s," in Communism: National and International, ed. Kimmo Rentola and Tauno Saarela (Helsinki: Finnish Historical Society, 1998

Kero, Reino. Neuvosto-Karjalaa rakentamassa: Pohjois Americkan suomalaiset tekniikan tuojina 1930-luvun Neuvosto-Karjalassa. Helsinki: Suomen Historiallinen Seura, 1983. Kostiainen, Auvo. "Genocide in Soviet Karelia: Stalin's Terror and the Finns of Soviet Karelia." Scandinavian Journal of History, 21, no. 4 (1996).

Kostiainen, Auvo. Loikkarit: Suuren lamakauden laiton siirtolaisuus Neuvostoliittoon. Helsinki: Otava, 1987.

Martin, Terry. "Modernization or Neo-Traditionalism? Ascribed Nationality and Soviet Primordialism," in Stalinism: New Directions. Ed. Sheila Fitzpatrick. London: Routledge, 2000.

Martin, Terry. The Affirmative Action Empire: Nations and Nationalism in the Soviet Union, 1923-1939. Ithaca, NY: Cornell University Press, 2001.

Matley, Ian. "The Dispersal of the Ingrian Finns." Slavic Review 38, no. 1 (1979). Nelson, Allan. The Nelson Brothers: Finnish American Radicals from the Mendocino Coast. Ed. Russell and Sylvia Bartley. Ukiah, CA: Mendocino County Historical Society and Mendocino County Museum, 2005.

Sevander, Mayme. Red Exodus: Finnish-American Emigration to Russia. Duluth, MN: OSCAT, 1993.

Takala, Irina. Finny v Kareliia i v Rossii. St. Petersburg, Russia: Neva, 2002.

Takala, Irina. "From the Frying Pan into the Fire: North American Finns in Soviet Karelia." In Karelian Exodus: Finnish Communities in North American and Soviet Karelia during the Depression Era. Eds. Ronald Harpelle, Varpu Lindstrom and Alexis E. Pogorelskin. Beaverton, ON: Aspasia Books, 2004. 
Vihavainen, Timo. "Framing the Finnish Experience." In Karelian Exodus: Finnish Communities in North American and Soviet Karelia during the Depression Era. Eds. Ronald Harpelle, Varpu Lindstrom and Alexis E. Pogorelskin. Beaverton, ON: Aspasia Books, 2004.

Weiner, Amir. Making Sense of War: The Second World War and the Fate of the Bolshevik Revolution. Princeton, NJ: Princeton University Press, 2001. 